\title{
Strategi Pengembangan Restoran Halal Sebagai Penunjang Hotel Syariah (Studi Kasus Di Unida Gontor Inn, Universitas Darussalam Gontor Ponorogo)
}

\author{
Agensy Nurmaydha, Siti Asmaul Mustaniroh, Sucipto \\ Universitas Brawijaya Malang \\ agensynurmaydha@gmail.com
}

https://doi.org/10.21107/dinar.v5i2.5006

\begin{abstract}
ABSTRAK
Pariwisata syariah adalah tren baru pariwisata di dunia. Peluang wisata syariah berpotensi sangat menguntungkan. Pariwisata syariah mengakomodasi banyak industri, seperti makanan halal, restoran halal, dan hotel syariah. Salah satu aspek yang harus dipenubi dalam sertifikasi hotel syariah adalah restoran bersertifikat halal. UNID A Gontor Inn adalah salah satu hotel di Ponorogo yang dimiliki oleh Universitas Darussalam (UNID A) Gontor yang dipersiapkan untuk menjadi hotel syariah.

Tujuan dari penelitian ini adalah untuk mengetahui strategi pengembangan restoran hotel menjadi restoran halal sebagai penunjang hotel syariah. Penentuan strategi pengembangan menggunakan metode Analytical Hierarchy Process (AHP).

Hasil penelitin adalah perhitungan AHP diperoleh tingkat prioritas faktor tingkat hasil tertinggi, sistem produksi 0,454, prioritas tujuan tingkat tertinggi adalah sertifikat restoran halal 0,412, strategi alternatif tingkat prioritas adalah bobot tertinggi, penentuan standar kualitas produksi 0,316. Manajemen hotel harus fokus pada penentuan standar kualitas produksi terkait input, proses dan output, termasuk pembelian bahan baku, penerimaan, pemiliban, penyimpanan, pemrosesan, dan penyajian sesuai dengan Sistem Jaminan Halal (SJH) sebingga dapat mendukung sertifikasi restoran halal untuk. mendukung hotel syariah, serta menjadi hotel syariah di Ponorogo.
\end{abstract}

Kata Kunci : AHP; Hotel Syariah, Restoran Halal, Strategi 


\section{PENDAHULUAN}

Wisata syariah merupakan trend baru pariwisata di dunia. Utilizing the World Tourism Organization (UNWTO) menyatakan wisatawan Muslim di dunia berkontribusi 140 miliar dolar AS pada 2013 dan diprediksi meningkat 238 dolar AS pada 2019 (Battour \& Ismail, 2016). Hal ini merupakan peluang besar karena wisata syariah mewadahi banyak industri, diantaranya makanan halal, restoran halal, souvenir halal, dan hotel syariah. Makanan halal sangat penting karena sebagian besar penduduk Indonesia muslim (Siradjuddin, 2013). Wisata syariah mengalami perkembangan pesat yang kini mengarah pada pemenuhan gaya hidup. Pelopor hotel syariah di Indonesia adalah Hotel Sofyan. Hotel tersebut mampu meningkatkan pengunjung hingga 80\% setelah menerapkan konsep syariah.

Penelitian ini menggunakan metode kuantitatif AHP. (Koç \& Burhan, 2015), AHP merupakan sebuah model yang digunakan untuk mencari urutan prioritas atau rangking dari berbagai alternatif dalam pemecahan suatu permasalahan yang memiliki keunggulan mampu mengambil keputusan secara efektif atas permasalahan dengan menyederhanakan ke dalam bagian-bagian (hierarki), dan mensintesis berbagai pertimbangan untuk menetapkan variabel pada setiap level dengan pembobotan prioritas tertinggi yang mampu memberikan alternatif strategi pada pengambilan kebijakan oleh tim manajemen.

Identifikasi aspek manajemen hotel diperlukan untuk memperbaiki fasilitas UNIDA Gontor Inn agar mendukung sertifikasi hotel syariah dengan melakukan perbaikan fasilitas yang kurang sesuai. Metode AHP tidak hanya diimplementasikan untuk fasilitas tapi juga sistem dengan mempertimbangkan masukan internal dan eksternal (Saaty, 2008). Diharapkan dengan tersertifikasi halal restoran akan menunjang manajemen hotel untuk memperoleh sertifikat hotel syariah. Sertifikasi hotel syariah di UNIDA Gontor Inn akan memberikan kenyamanan bagi pengunjung hotel dan menjadi percontohan hotel syariah di wilayah Kabupaten Ponorogo untuk mendukung wisata syariah yang sedang berkembang di Indonesia.

\section{TINJAUAN PUSTAKA}

\section{Strategi}

Kata "strategi" berasal dari bahasa Yunani, yaitu "strategos" (stratos=militer dan ag=memimpin), yang berarti "generalship” atau sesuatu yang dikerjakan oleh para jenderal perang dalam membuat rencana untuk memenangkan perang. Berdasarkan Kamus Besar Bahasa Indonesia (KBBI), strategi merupakan rencana yang cermat mengenai kegiatan untuk mencapai sasaran secara khusus. Strategi merupakan alat untuk mencapai tujuafn perusahaan dalam kaitannya dengan tujuan jangka panjang, program tindak lanjut, serta prioritas alokasi sumber daya.

Pemahaman yang baik mengenai konsep strategi dan konsep-konsep lain yang berkaitan, sangat menentukan suksesnya strategi yang disusun. Konsep-konsep tersebut adalah distinctive competence dan competitive advantage. Distinctive competence adalah tindakan yang dilakukan oleh perusahaan agar dapat melakukan kegiatan lebih baik dibandingkan dengan 
pesaingnya. Suatu perusahaan yang memiliki kekuatan yang tidak mudah ditiru oleh perusahaan pesaing dipandang sebagai perusahaan yang memiliki distinctive competence. Competitive advantage adalah kegiatan spesifik yang dikembangkan oleh perusahaan agar lebih unggul dibandingkan dengan pesaingnya. Keunggulan bersaing disebabkan oleh pilihan strategi yang dilakukan perusahaan untuk merebut peluang pasar.

\section{Restoran Syariah}

Restoran syariah adalah usaha kuliner yang menyediakan makanan halal, yakni segala sesuatu yang diperbolehkan oleh syari'at untuk dikonsumsi secara syariah. Agama Islam menganjurkan kepada pemeluknya untuk memakan makanan yang halal dan baik. Makanan halal adalah makanan yang didapatkan dan difungsikan melalui syariat yang diridhai Allah. Sedangkan makanan yang baik adalah makanan yang bergizi atau bermanfaat bagi tubuh.

Restoran syariah harus menyediakan makanan yang halal dan baik. Kriteria halal pada makanan harus memenuhi paling tidak tiga kriteria, yaitu halal zatnya, halal cara memperolenya, dan halal cara pengolahannya.

Makanan yang halal menurut zatnya adalah makanan yang dari dasarnya halal untuk di konsumsi. Dan telah di tetapkan kehalalannya dalam kitab suci al-qur'an dan al-hadist. Centohnya adalah daging sapi, ayam, kambing, buah-buahan seperti apel, kurma, anggur, dan lain sebagainya. Halal cara memperolehnya yaitu makanan yang di didapat dengan cara yang baik dan sah menurut syariat islam, Makanan akan menjadi haram apabila cara memperolehnya dengan jalan yang batil karena itu bisa merusak tubuh kita dan merugikan orang lain serta dilarang oleh syariat. Contoh cara memperoleh makanan dengan cara yang baik adalah dengan cara membeli dengan uang sendiri, bertani, hadiah, dan lain sebagainya. Adapun dari makanan yang diperoleh dari makanan yang batil adalah dengan cara mencuri, merampok, menyamun, dan lain sebagainya.

Halal cara pengolahannya yaitu makanan yang semula halal dan akan berubah menjadi makanan haram apabila cara pengolahannya tidak sesuai dengan syeriat islam. Contohnya buah anggur, makanan ini halal tetapi karena telah diolah menjadi minuman keras maka minuman ini menjadi haram.

\section{Hotel Syariah}

Pengertian hotel Syariah adalah usaha bisnis penginapan dengan tata cara operasional dan manajemen secara syariah Islam. Konsep syariah yang ditonjolkan pada usaha hotel ini adalah moto, logo, ornamen interior, fasilitas kamar, seragam, pelayanan, pakaian karyawan yang berbasis nilai-nilai syariah (Widyarini, 2013: 2). Tujuan dari usaha hotel syariah adalah meminimalisir dari tingkah laku yang bertentangan dengan larangan agama Islam seperti praktek perzinahan, minuman keras, pshycotropika, perjudian (Ariffin, 2015).

Dari Peraturan Menteri Pariwisata dan Ekonomi Kreatif Nomor 2 tahun 2014 tentang Pedoman Penyelenggaraan Usaha Hotel Syariah yang diundangkan pada 17/1/204, Usaha Hotel Syariah adalah usaha hotel yang penyelenggaraannya harus 
memenuhi kriteria Usaha Hotel Syariah yang mencakup aspek produk, pelayanan, dan pengelolaan.Hotel Syariah adalah salah satu model hotel yang menawarkan fasilitas yang sesuai dengan nilai Islam, sehingga mampu meminimalisir adanya praktek perzinahan, minuman keras, pshycotropika, perjudian. Apabila hotel tegas dalam memberlakukan syarat-syarat tamu pengunjung, maka masyarakat juga akan berpikir ulang untuk melakukan yang melanggar pidana.

Menurut Permen Parekraf No. 2/2014, terdapat dua jenis Kriteria Hotel Syariah yang telah dibagi menjadi Kriteria Hotel Syariah Hilal 1 dan Kriteria Hotel Syariah Hilal 2. Hilal-1 adalah penggolongan untuk usaha hotel Syariah yang dinilai memenuhi seluruh kriteria Usaha Hotel Syariah yang diperlukan untuk melayani kebutuhan minimal wisatawan Muslim. Mulai dari aspek produk yang terdiri dari: 1) Toilet Umum (Public Rest Room) 2) Kamar Tidur Tamu 3) Kamar Mandi Tamu 4) Dapur 5) Ruang Karyawan 6) Ruang Ibadah 7) Kolam Renang 8) Spa. Untuk aspek pelayanan terdiri dari : 1) Kantor Depan 2) Tata Graha 3) Makan dan Minum 4) Olahraga, rekreasi dan kebugaran 5) Spa (Apabila Ada) 6) Fasilitas Hiburan dan lain-lain. Sedangkan aspek pengelolaan terdiri dari manajemen usaha dan Sumber Daya Manusia.

Hotel Syariah Hilal 2 merupakan hotel dengan penggolongannya untuk melayani kebutuhan moderat wisatawan Muslim. Kriteria mutlak untuk usaha hotel syariah hilal-2 terdiri dariAspek Produk mulai dari : 1) Lobby, 2) Front Office; 3) Toilet Umum (Public Rest Room); 4) Kamar Tidur Tamu 5) Kamar Mandi Tamu 6) Dapur; 7) Ruang Karyawan; 8) Ruang Ibadah 9) Interior/ ornamen 10) Kolam renang 11) Spa. Untuk aspek pelayanan terdiri dari 1) Kantor Depan; 2) Tata Graha; 3) Makan dan minum; 4)Public bar Olahraga; 5) rekreasi dan kebugaran; 6)Kolam renangSpa (Apabila Ada); 7)Konsultasi; 8) Keramah tamahan; 9) Fasilitas Hiburan.

Sedangkan untuk Aspek Pengelolaan berupa: 1) Organisasi yang memiliki Struktur organisasi yang mengakomodasi Dewan Pengawas Syariah, kemudian memiliki Standar Operating Procedure Hotel Syariah dan memiliki pernyataan tertulis yang menyatakan usaha dikelola secara Syariah; 2) Manajemen Usaha; 3) Sumber Daya Manusia yang memiliki dan melaksanakan program pengembangan kompetensi SDM yang bermuatan Syariah.

\section{METODE PENELITIAN}

Pelaksanaan penelitian merupakan rencana terstruktur yang dibuat untuk memperoleh jawaban atas pertanyaan atau permasalahan untuk mendapat solusi (Razalli, Abdullah, \& Hassan, 2012). Penelitian dilaksanakan di UNIDA Gontor Inn, Universitas Darussalam Gontor, Ponorogo, Jawa Timur yang meliputi katering dalam dan katering luar restoran pada Desember 2017 sampai Februari 2018. Pengolahan data di Laboratorium Komputasi dan Analisis Sistem, Jurusan Teknologi Industri Pertanian, Fakultas Teknologi Pertanian, Universitas Brawijaya Malang. Penelitian ini menggunakan metode deskriptif kuantitatif menggunakan metode AHP. 


\section{HASIL DAN PEMBAHASAN}

Strategi pengembangan restoran halal bertujuan untuk memperoleh alternative startegi terbaik dalam pengembangan restoran halal di Resto UNIDA Gontor Inn. Penggunaan metode AHP dikarenakan metode ini banyak digunakan untuk pengambilan keputusan masalah yang bersifat multi kriteria yang membantu kerangka berpikir manusia, meliputi faktor logika, pengalaman, pengetahuan, emosi, dan rasa yang dioptimsikan ke dalam suatu proses sistematis (Rahmayanti, 2010). (Lu \& Mao, 2015) menyebutkan jika AHP menarik perhatian banyak peneliti karena menggunakan sifat matematis yang bagus serta data yang dibutuhkan lebih mudah didapat dan mampu memecahkan masalah keputusan yang kompleks.

\section{Karakteristik Responden Pakar}

Pemilihan responden pakar berdasar pada pengetahuan dan pengalaman responden terkait dengan penelitian dan ahli di bidang masing-masing. Pakar yang dipilih merupakan orang-orang yang terkait institusi, memiliki wewenang, mengetahui hukum syariah, sehingga mampu memberikan penilaian terhadap faktor, tujuan, dan alternatif strategi pengembangan restoran halal di UNIDA Gontor Inn. (Dalalah, Al-oqla, \& Hayajneh, 2010), mengemukakan bahwa responden pakar pada penelitian AHP merupakan orang yang berkompeten, menguasai, mempengaruhi pengambilan kebijakan atau mengetahui informasi yang dibutuhkan. Responden pakar pada penelitian ini berjumlah 8 orang, terdiri dari direktur UNIDA Gontor Inn, staf hotel, staf resto, Ketua MUI Ponorgo, Dinas Pariwisata Ponorogo, Dosen Hukum Syariah, perwakilan katering dalam (Madam Mulyono), perwakilan katering luar (Bu Yuli pemilik rumah makan sate gulai kambing).

\section{Konsistensi Responden Pakar}

Pengolahan data berdasar hasil kuesioner responden ahli, kemudian dicari rata-rata geometri. Selanjutnya, perhitungan pada perbandingan hierarki mulai dari perbandingan berdasar tujuan, faktor, dan alternatif strategi. Selanjutnya, mencari nilai geometri, matriks perbandingan, vector eigen ( $)$, indeks konsistensi (CI), dan rasio konsistensi (CR). Menurut Lai (2015), penilaian dianggap konsisten apabila nilai $\mathrm{CR}<0,1$, jika $\mathrm{CR}>0,1$ maka nilai perbandingan berpasangan pada matriks kriteria yang diberikan tidak konsisten dan harus dilakukan penyebaran kuesioner ulang. Nilai hasil perhitungan CR disajikan pada Tabel 1.

\section{Tabel 1}

\section{Rasio Konsistensi Responden Pakar}

\begin{tabular}{llccc}
\hline No. & \multicolumn{1}{c}{ Program, Faktor, Tujuan } & Level & Nilai CR & Konsistensi \\
\hline 1. & Strategi Pengembangan Restoran & Antar Faktor & 0,082 & $\sqrt{ }$ \\
& Halal & & \\
2. & Sistem Produksi & 0,080 & $\sqrt{ }$ \\
& Sumberdaya Manusia & Antar Tujuan & 0,096 & $\sqrt{ }$ \\
& Pasar & & 0,002 & $\sqrt{ }$
\end{tabular}


3. Sertifikat Halal Produk

$\begin{array}{ccc} & 0,071 & \sqrt{ } \\ \text { Antar } & 0,085 & \sqrt{ } \\ \text { Alternatif } & 0,064 & \sqrt{ } \\ \text { Strategi } & 0,055 & \sqrt{ }\end{array}$

Berpengetahuan Halal

Strategi

Konsistensi Metode Pengolahan

Pengembangan Menu Halal

Kepercayaan Konsumen

0,075

$\sqrt{ }$
$\sqrt{ }$
$\sqrt{ }$
$\sqrt{ }$

\section{Sumber: Data Diolah (2018)}

\section{Pembobotan Level Faktor}

Level tertinggi hierarki AHP adalah level program. Pada level program, terdapat tiga elemen faktor di bawahnya. Tiga elemen faktor tersebut dibandingkan secara berpasangan yaitu antara sistem produksi, sumberdaya manusia, dan pasar (Rahmayanti, 2010). Hasil pembobotan level faktor terdapat pada Tabel 2. Hasil pembobotan AHP pada tiap level yang disajikan pada Gambar 1.

Tabel 2

\section{Pembobotan Level Prioritas Pengembangan Restoran Halal UNIDA Gontor Inn}

\begin{tabular}{clcc}
\hline No. & \multicolumn{1}{c}{ Faktor } & Bobot & Prioritas \\
\hline 1. & Sistem Produksi & $\mathbf{0 , 4 5 4}$ & $\mathbf{1}$ \\
2. & Sumber Daya Manusia & 0,225 & 3 \\
3. & Pasar & 0,321 & 2
\end{tabular}

\section{Sumber: Data Diolah (2018)}

Tabel 2 menunujukkan sistem produksi memiliki bobot tertinggi diantara faktor yang lainnya. (Fortunella, Tama, \& Eunike, 2014), sistem produksi memiliki komponen struktural dan fungsional untuk menunjang kontinuitas operasional sistem serta terdapat interaksi antar variabel untuk mencapai tujuan. Variabel tersebut antara lain imput, process, output. Input meliputi urutan, jumlah, dan jenis operasi. Proses membutuhkan manajemen yang baik agar konsisten, terlebih untuk menghasilkan menu halal, diperlukan SOP yang mendukung proses produksi. Output berupa produk maupun hasil samping seperti limbah dan informasi. (Dan et al., 2013), sistem produksi pada usaha kuliner atau restoran memerlukan SOP sebagai acuan kerja yang bertujuan agar semua pekerjaan memiliki standar yang sama dan konsisten, misalnya standar resep, penggunaan bahan baku, serta cara memasak. 


\section{Gambar 1}

\section{Hierarki Strategi Pengembangan Restoran UNIDA Gontor Inn}

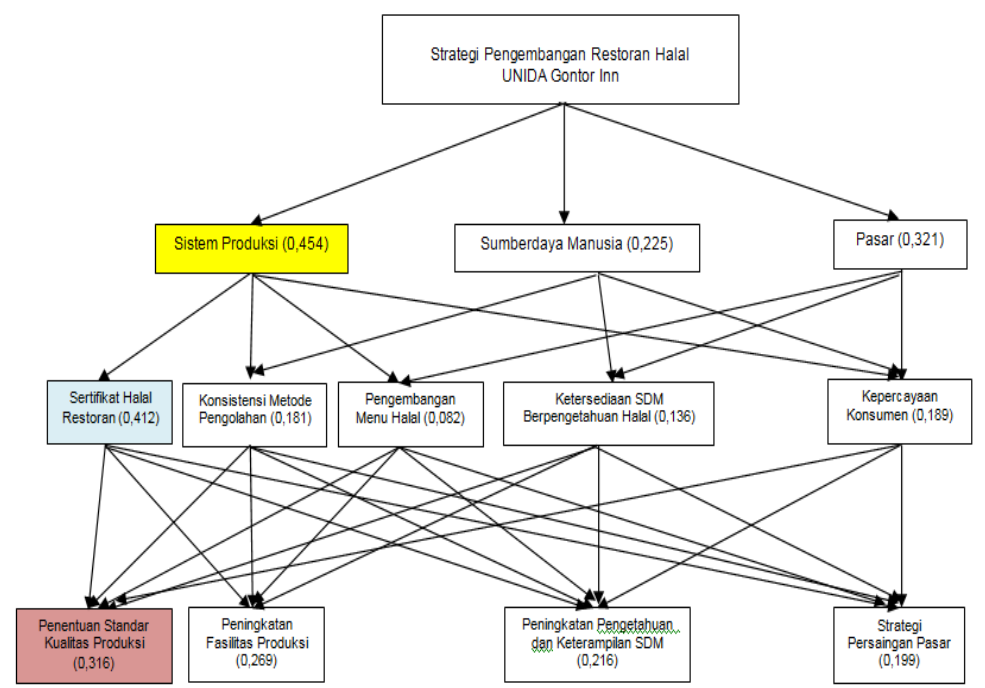

\section{Pembobotan Level Tujuan}

Program yang dideskripsikan sebelumnya memerlukan faktor pendukung untuk keberhasilan dalam pencapaian strategi. Pembobotan masing-masing tujuan untuk mendukung strategi pengembangan restoran halal di Resto UNIDA Gontor Inn dapat dilihat pada Tabel 3 .

Tabel 3

Pembobotan Level Tujuan Pengembangan Restoran Halal UNIDA Gontor Inn

\begin{tabular}{|c|c|c|c|}
\hline No. & Level Faktor & Tujuan & Bobot \\
\hline \multirow[t]{5}{*}{1.} & Sistem & Sertifikat Halal Restoran & 0,483 \\
\hline & Produksi & Konsistensi Metode Pengolahan & 0,196 \\
\hline & & Pengembangan Menu Halal & 0,060 \\
\hline & & Ketersediaan SDM Berpengetahuan Halal & 0,101 \\
\hline & & Kepercayaan Konsumen & 0,160 \\
\hline \multirow[t]{6}{*}{2.} & Sumber Daya & Sertifikat Halal Restoran & 0,229 \\
\hline & Manusia & Konsistensi Metode Pengolahan & 0,205 \\
\hline & & Pengembangan Menu Halal & 0,108 \\
\hline & & Ketersediaan SDM Berpengetahuan & 0,256 \\
\hline & & Halal & 0,202 \\
\hline & & Kepercayaan Konsumen & \\
\hline \multirow[t]{5}{*}{3.} & Pasar & Sertifikat Halal Restoran & 0,439 \\
\hline & & Konsistensi Metode Pengolahan & 0,143 \\
\hline & & Pengembangan Menu Halal & 0,092 \\
\hline & & Ketersediaan SDM Berpengetahuan Halal & 0,102 \\
\hline & & Kepercayaan Konsumen & 0,224 \\
\hline
\end{tabular}

Sumber: Data Diolah (2018) 


\section{Pembobotan Level Alternatif Strategi}

Pembobotan level alternatif strategi diperoleh dari data pengukuran prioritas kepentingan tujuan dari masing-masing faktor. Hasil pembobotan terdapat pada Tabel 4.

\section{Tabel 4}

Pembobotan Alternatif Strategi Pengembangan Restoran Halal

\begin{tabular}{clc}
\hline No. Level Tujuan & \multicolumn{1}{c}{ Alternatif Strategi } & Bobot \\
\hline 1. Sertifikat Halal & Penentuan Standar Kualitas Produksi & $\mathbf{0 , 4 7 2}$ \\
Produk & Peningkatan Fasilitas Produksi & 0,220 \\
& Peningkatan Pengetahuan dan Keterampilan SDM & 0,185 \\
& Strategi Persaingan Pasar & 0,123 \\
2. Konsistensi & Penentuan Standar Kualitas Produksi & 0,135 \\
Metode & Peningkatan Fasilitas Produksi & $\mathbf{0 , 3 2 5}$ \\
Pengolahan & Peningkatan Pengetahuan dan Keterampilan SDM & 0,298 \\
& Strategi Persaingan Pasar & 0,242 \\
3. Pengembangan & Penentuan Standar Kualitas Produksi & $\mathbf{0 , 4 0 4}$ \\
Menu Halal & Peningkatan Fasilitas Produksi & 0,170 \\
& Peningkatan Pengetahuan dan Keterampilan SDM & 0,106 \\
& Strategi Persaingan Pasar & 0,320 \\
4. Ketersediaan & Penentuan Standar Kualitas Produksi & 0,155 \\
SDM & Peningkatan Fasilitas Produksi & 0,234 \\
Berpengetahuan & Peningkatan Pengetahuan dan Keterampilan & $\mathbf{0 , 3 6 9}$ \\
Halal & SDM & 0,242 \\
& Strategi Persaingan Pasar & \\
Kepercayaan & Penentuan Standar Kualitas Produksi & 0,226 \\
Konsumen & Peningkatan Fasilitas Produksi & $\mathbf{0 , 3 9 0}$ \\
& Peningkatan Pengetahuan dan Keterampilan SDM & 0,144 \\
& Strategi Persaingan Pasar & 0,240 \\
\hline
\end{tabular}

\section{Prioritas Level Tujuan}

Sumber: Data Diolah (2018)

Setelah dilakukan pembobotan pada masing-masing level faktor, level tujuan, dan level alternatif strategi selanjutnya dilakukan sintesis untuk mendapatkan bobot alternatif secara keseluruhan pada masing-masing kriteria di setiap level. Hasil perhitungan global priority level program, faktor, dan tujuan pada Tabel 5. Pembobotan global priority menunjukkan sertifikat halal restoran memiliki bobot tertinggi, yang artinya faktor tersebut harus lebih diprioritaskan. Sertifikat halal restoran menjadi prioritas utama karena dengan adanya sertifikasi halal dapat memberikan kepastian kehalalan pada suatu produk sehingga menentramkan batin konsumen. (MUI, 2013) menyatakan pentingnya sertifikasi halal pada restoran karena makanan masa kini cenderung memanfaatkan ilmu pengetahuan dan teknologi dan bahan tambahan pangan yang menimbulkan titik kontrol kehalalan produk pangan yang harus dicermati dari berbagai segi. 
UNIDA Gontor Inn bertekad ingin menjadi hotel syariah, selain untuk media pembelajaran bisnis, hal tersebut sebagai media dakwah dan percontohan hotel syariah di Ponorogo. Sertifikat halal restoran menjadi hal mutlak yang harus dipenuhi agar hotel bersertifikat syariah. Keadaan di lapangan menunjukkan jika manajemen hotel dari awal berdiri hotel sudah menerapkan konsep Islami, namun ada beberapa hal yang harus diperbaiki terutama resto. Permasalahan yang terjadi, pihak hotel belum mengetahui prosedur pengajuan restoran halal dan hotel syariah. Untuk itu, perlu adanya tim manajemen halal yang bertugas untuk sosialisasi kepada staf dan rekanan katering luar untuk membantu dokumen pengajuan sertifikasi halal.

Tabel 5

Pembobotan Global Priority Level Program, Faktor, dan Tujuan

Sumber: Data Diolah (2018)

\begin{tabular}{ccccccc}
\hline Program & Faktor & Tujuan & Bobot & Global Priority & Bobot & $\begin{array}{c}\text { Priorita } \\
\text { s }\end{array}$ \\
& & A & 0,483 & A & $\mathbf{0 , 4 1 2}$ & $\mathbf{1}$ \\
& Sistem & B & 0,196 & & & \\
& Produksi & C & 0,060 & B & 0,181 & 3 \\
Memilih & $(0,454)$ & D & 0,108 & & & \\
strategi & & E & 0,159 & C & 0,082 & 5 \\
terbaik & & A & 0,229 & & & \\
untuk & Sumber & B & 0,205 & D & 0,136 & 4 \\
pengemban & Daya & C & 0,108 & & & \\
gan & Manusia & D & 0,256 & E & 0,189 & 2 \\
restoran & $(0,225)$ & E & 0,202 & & & \\
halal di & & A & 0,439 & & & \\
UNIDA & & B & 0,143 & & & \\
Gontor Inn & Pasar & C & 0,092 & & & \\
& $(0,32$ & C & D & 0,102 & & \\
\end{tabular}

Keterangan :

$A=$ Sertifikat Halal Restoran

$\mathrm{B}=$ Konsistensi Metode Pengolahan

$\mathrm{C}=$ Pengembangan Menu Halal

$\mathrm{D}=$ Ketersediaan SDM Berpengetahuan Halal

$\mathrm{E}=$ Kepercayaan Konsumen

\section{Prioritas Alternatif Strategi}

Cara perhitungan pembobotan global priority sama dengan perhitungan pada level sebelumnya. Hasil pembobotan global priority pada Tabel 6. Global priority dari kriteria alternatif strategi ditunjukkan pada Tabel 6. Alternatif strategi pengembangan restoran halal secara berurutan yaitu penentuan standar kualitas produksi, peningkatan fasilitas produksi, peningkatan pengetahuan dan keterampilan SDM, strategi persaingan pasar. 
(Purnomo, 2011) menyatakan tujuan prioritas strategi untuk mengidentifikasi lingkungan menjadi target pasar dengan menganalisis lingkungan internal dan eksternal untuk mengukur kekuatan dan kelemahan serta peluang dan ancaman yang dihadapai.

Alternatif strategi yang diperoleh melalui identifikasi kekuatan, kelemahan, peluang, dan ancaman yang dimiliki UNIDA Gontor Inn untuk menunjang sertifikasi restoran halal sebagai penunjang hotel syariah. Kekuatan yang dimilik yaitu pangsa pasar besar, khususnya keluarga besar Pondok Modern Darussalam Gontor serta nuansa Islami yang disuguhkan karena terletak di dalam kampus pesantren. Kelemahan yaitu pengetahuan dan kesadaran tentang makanan halal dan restoran halal masih kurang, sebagian menu di resto dipesan dari katering luar sehingga proses pengawasan terhadap kehalalan sulit dilakukan. Peluang yang dimiliki yaitu keberadaan restoran halal di Ponorogo masih minim (hanya 3 rumah makan) sehingga masih sangat terbuka. Ancaman yang dimiliki yaitu penerimaan konsumen tentang restoran halal terkait dengan pengetahuan, kesadaran, dan tingkat religius.

Proritas pertama, alternatif strategi penentuan standar kualitas produksi. Kualitas yang dimaksud yaitu kualitas bahan baku terkait kehalalan dan mutu. Kualitas diartikan sebagai atribut yang menyertai suatu produk, yang menjadi ciri suatu produk. Tim manajemen hotel harus menyusun dan mengimplementasikan SOP sesuai Manual SJH sebagai acuan, mulai tahap pembelian bahan, penerimaan bahan, seleksi bahan, penyimpanan bahan, pengolahan bahan, formulasi menu baru, fasilitas produksi, peralatan dan mesin yang digunakan, hingga penyajian (Zailani, Kanapathy, Iranmanesh, \& Tieman, 2015).

Tabel 6

Pembobotan Global Priority Level Alternatif Strategi

\begin{tabular}{ccccc}
\hline $\begin{array}{c}\text { Prioritas Global } \\
\text { Tujuan }\end{array}$ & $\begin{array}{c}\text { Alternatif } \\
\text { Strategi }\end{array}$ & Bobot & $\begin{array}{c}\text { Prioritas } \\
\text { Global }\end{array}$ & Prioritas \\
\hline A $(0,412)$ & Strategi X & 0,471 & & \\
& Strategi Y & 0,220 & $\mathbf{X}$ & $\mathbf{1}$ \\
& Strategi Z & 0,185 & $\mathbf{( 0 , 3 1 6 )}$ & \\
& Strategi U & 0,123 & & \\
\hline B $(0,181)$ & Strategi X & 0,135 & & \\
& Strategi Y & 0,325 & & \\
& Strategi Z & 0,298 & & \\
& Strategi U & 0,242 & Y $(0,269)$ & \\
\hline C $(0,082)$ & Strategi X & 0,404 & & \\
& Strategi Y & 0,170 & & \\
& Strategi Z & 0,105 & & \\
& Strategi U & 0,320 & &
\end{tabular}




\begin{tabular}{ccccc}
$\mathrm{D}(0,136)$ & Strategi $\mathrm{X}$ & 0,155 & $\mathrm{Z}(0,216)$ & 3 \\
& Strategi $\mathrm{Y}$ & 0,234 & & \\
& Strategi $Z$ & 0,370 & & \\
& Strategi $\mathrm{U}$ & 0,242 & & \\
\hline $\mathrm{E}(0,189)$ & Strategi $\mathrm{X}$ & 0,226 & & \\
& Strategi $\mathrm{Y}$ & 0,390 & $\mathrm{U}(0,199)$ & \\
& Strategi $Z$ & 0,144 & & \\
& Strategi $\mathrm{U}$ & 0,240 & & $\mathbf{1}$ \\
\hline
\end{tabular}

Sumber: Data Diolah (2018)

Keterangan :

$\mathrm{X}=$ Penentuan Standar Kualitas Produksi

$\mathrm{Y}=$ Peningkatan Fasilitas Produksi

$\mathrm{Z}=$ Peningkatan Pengetahuan dan Keterampilan SDM

$\mathrm{U}=$ Strategi Persaingan Pasar

(Ermis, 2017), adanya SOP yang jelas pada tiap tahap akan mempermudah pengontrolan dan pengawasan. Produk dari hulu hingga hilir terjamin kehalalan dan terhindar dari kontaminasi fisik, kimia, dan bahan najis. Prioritas strategi dalam mengembangkan restoran yaitu meningkatkan mutu dan menjaga kehalalan. Strategi tersebut bertujuan menjaga dan mempertahankan kepercayaan dan loyalitas konsumen terhadap kualitas produk.

\section{KESIMPULAN}

Strategi pengembangan Restoran UNDA Gontor Inn sangat berpotensi dikembangkan. Hasil pembobotan menggunakan metode AHP diperoleh hasil prioritas level faktor secara berurutan yaitu sistem produksi $(0,454)$, pasar $(0,321)$, sumberdaya manusia $(0,225)$. Prioritas level tujuan secara berurutan yaitu sertifikat halal restoran $(0,412)$, kepercayaan konsumen $(0,189)$, konsistensi metode pengolahan $(0,181)$, dan pengembangan menu halal $(0,082)$. Prioritas level alternatif strategi secara berurutan yaitu penentuan standar kualitas produksi $(0,316)$, peningkatan fasilitas produksi $(0,269)$, peningkatan pengetahuan dan keterampilan $\operatorname{SDM}(0,216)$ dan strategi persaingan pasar $(0,1999)$. Pihak manjemen hotel harus lebih fokus dalam menentukan standar kualitas produksi yang terkait dengan input, proses, dan output, meliputi pembelian bahan baku, penerimaan, penyimpanan, pengolahan, dan penyajian.

\section{DAFTAR PUSTAKA}

Battour, M., \& Ismail, M. N. (2016). Halal tourism: Concepts, practises, challenges and future. Tourism Management Perspectives, 19, 150-154. https://doi.org/10.1016/j.tmp.2015.12.008 
Dalalah, D., Al-oqla, F., \& Hayajneh, M. (2010). Application of the Analytic Hierarchy Process ( AHP) in Multi- Criteria Analysis of the Selection of Cranes. Jordan Journal of Mechanical and Industrial Engineering, 4(5), 567-578.

Dan, P., Usaha, P., Tania, S., Harjanti, D., Si, M., Bisnis, P. M., ... Kunci, K. (2013). Pada Restoran Pondok Kemangi Di Banjarmasin. 1(1).

Ermis, E. (2017). Halal status of enzymes used in food industry. Trends in Food Science and Technology, 64(2017), 69-73. https://doi.org/10.1016/j.tifs.2017.04.008

Fortunella, A., Tama, I. P., \& Eunike, A. (2014). Simulation Model of Production System with System Dynamic to Support Production Capacity Planning. Jurnal Rekayasa Dan Manajemen Sistem Industri, 3(2), 256-267.

Koç, E., \& Burhan, H. A. (2015). An Application of Analytic Hierarchy Process (AHP) in a Real World Problem of Store Location Selection. Advances in Management \& Applied Economics, 5(1), 41-50.

Lu, H. A., \& Mao, Y. R. (2015). Evaluation of airport conditions to attract foreign low cost carriers: A case study of Taiwan. Journal of Air Transport Management, 42, 297-305. https://doi.org/10.1016/j.jairtraman.2014.12.003

MUI, L. (2013). Majelis ulama indonesia. 8358748(51), 4-7.

Noor Rashidah Mohamad Ariffin. (2015). Konsep Hifz Ad-Din Dalam Pengurusan Hotel Patuh Syariah. Prosiding Seminar Pengurusan Islam: Ke Arah Pemantapan Ummah.

Purnomo, D. (2011). Strategi pengembangan agroindustri halal dalam mengantisipasi bisnis halal global.

Rahmayanti, R. (2010). Analisis Pemilihan Supplier Menggunakan Metode Analytical Hierarchy Process (Ahp) (Studi Kasus Pada PT Cazikhal). 168.

Razalli, M. R., Abdullah, S., \& Hassan, M. G. (2012). Developing a Model for Islamic Hotels: Evaluating Opportunities and Challenges. International Proceedings of Economics Development \& Research, 91-95.

Saaty, T. L. (2008). Decision making with the analytic hierarchy process. International Journal of Services Sciences, 1(1), 83. https://doi.org/10.1504/IJSSCI.2008.017590

Siradjuddin, A. (2013). Regulasi Makanan Halal. Regulasi Makanan Halal Di Indonesia, XIII, $101-122$.

Widyarini, W. (2013). Pengelolaan Hotel Syariah di Yogyakarta. Ekbisi.

Zailani, S., Kanapathy, K., Iranmanesh, M., \& Tieman, M. (2015). Drivers of halal orientation strategy among halal food firms. British Food Journal, 117(8), 2143-2160. https://doi.org/10.1108/BFJ-01-2015-0027 